\title{
Responses of Company Staff upon the Performance of Interns and Alumni of the Hospital Administration Program of Universitas Indonesia: A Descriptive Study
}

\author{
Badra Al-Aufa
}

Hospital Administration Department, Vocational Program, Universitas Indonesia

\section{Abstract}

Vocational education tends to educate with practice rather than with mere theory; and internship programs become an important process of vocational education. Hospital administration department at Vocational Program, Universitas Indonesia also runs an internship program. Based on the background, the author is interested to conduct a research regarding the staff responses upon the performance of the students of the

Corresponding Author: Badra Al-Aufa

badraalaufa@gmail.com

Received: 8 June 2018

Accepted: 17 July 2018

Published: 8 August 2018

Publishing services provided by Knowledge

(c) Badra Al-Aufa. This article is distributed under the terms of the Creative Commons

Attribution License, which permits unrestricted use and redistribution provided that the original author and source are credited.

Selection and Peer-review under the responsibility of the 2 nd ICVHE Conference Committee. hospital administration program. Quantitative and qualitative approaches have been used at the same time in this research. This research uses a cross-sectional design. The subjects of this study are the alumni and interns from the Hospital Administration Program, Vocational Program, Universitas Indonesia. Variable on this research consists of seven variables regarding the performance of the interns. Those are integrity (ethics and moral), expertise in hospital administration science (professionalism), Englishlanguage skill, expertise in information technology, expertise in communication, teamwork and self-development. Based on the result, interns mostly have good score for seven indicators and only the English-language skill has a less score. The component that has the highest score is the ability to use information technology devices and teamwork that is $30.4 \%$. Meanwhile, the ability to use English is the component that has the highest score as adequate rather than other components that is $30.4 \%$. Several problems have been expressed by informants such as the lack of ability to operate Microsoft excel and use foreign language. Some recommendations have also been conveyed by informants such as adding certification in operating computer program and also adding soft skills in educational process.

Keywords: intern, alumni, job performance, vocational program, hospital administration

\section{G OPEN ACCESS}




\section{Introduction}

Education is one of the most important things which people have to get in their life. Certainly, education takes an important role on the developing process of the country. As UNESCO also highlights that the distribution of personal incomes in society is powerfully related to the amount of education people have had [1]. That means if the nation want to have a good economics condition, the leader should provide a good education system so that people could afford high level of education.

Indonesia is one of enormous nations in the world. According to the number of population, Indonesia ranked $4^{\text {th }}$ in the world after China, India and United States. As a big nation, Indonesia has several challenges regarding providing educational process. Some challenges come from financial, governance and management, pedagogy, equity and quality aspect [2].

In the other hand, Indonesia meets one condition, which is could be an opportunity to accelerate economic circumstance that called demographic bonus so that labor number in Indonesia has increased over the year. Even though, there is a challenge to provide a good education which is could generate a skilled labor. Skilled labor also needed in order to compete with other labors especially in this globalization era whereas countries around the world are like borderless.

That condition also happens in ASEAN which is there is a program that integrates economic between ASEAN countries called ASEAN Economic Community (AEC). AEC brings several changes in the economic aspect such as connected economic toward consistence production, free market infestation, capital transfer, labor market which has general principal and equity among member countries [2].

In order to overcome that condition, Ministry of Education and Cultural of Indonesia has strategy to give special place for vocational education. That strategy results a virtuous circumstance whereas vocational education has risen significantly over the past decade.

Vocational education tends to educate with practice rather than only the theory whereas internship program become an important process of vocational education. Hospital administration department at Vocational Program, Universitas Indonesia also has run internship program in this education period.

Every student compulsorily takes internship subjects. Student starts internship program by choosing certain hospital that has agreement with the department. After that, student got field supervisor who supervised them during the internship program. Student should run internship program for around one month in one hospital. 
Because of the importance of the program, evaluation process should be executed in order to explore how the program has run by the student and hospital staff. Evaluation also has been executed in order to explore performance and behavior of the students during the program. Based on the background, writer interests to conduct a research regarding staff responses upon performance of student of hospital administration program.

\section{Method}

Quantitative and qualitative approaches have been used at the same time in this research. This research uses cross sectional design. Subject of this study is alumni and intern from Hospital Administration Program, Vocational Program, Universitas Indonesia. Population of this study is the company staff at selected internship and working places. Total population number is equal with the number of the internship students which are 23 people.

Variable on this research consists of seven variables regarding performance of interns. Those are integrity (ethics and moral), expertise in hospital administration science (professionalism), skill in using English, ability to information technology, expertise in communication, teamwork and self-development. Each variable has been assessed into four categories which are less, enough, good and very good.

Total sampling method has been used to selecting the sample of this research which is number of sample is 24 hospital staff. Data has been collected by giving a questionnaire to the sample via electronic mail and questionnaire that has been filled had been re-sent by respondents. Qualitative method has been used in order to explore problems and suggestion that have been given by the company staff and intern regarding performance of intern and alumni and several suggestions which can be used to increase a quality of education process. Information collected by interview with certain people so that sampling method is purposive sampling method.

\section{Result and Discussion}

Based on Table 1, respondents in this research are vice director of hospital, head of medical record department, head of human resource department, manager, alumni and intern.

Table 2 describes alumni and intern places during the assessment. Alumni and intern works in several departments such human resource, marketing, administration and 
TABLE 1: Respondents in qualitative phase.

$\begin{array}{lll}\begin{array}{ll}\text { Informant } \\ \text { Code }\end{array} & \begin{array}{l}\text { Informant Position } \\ \text { A }\end{array} & \begin{array}{l}\text { Vice Director of Administration and General Affair } \\ \text { (Hospital) }\end{array} \\ \text { B } & \text { Head of Medical Record Department (Hospital) } \\ \text { C } & \text { Head of Human Resource and Development (Hospital) } \\ \text { D } & \text { Manager (Non-hospital Institution) } \\ \text { E } & \text { Alumni } \\ \text { F } & \text { Alumni } \\ \text { G } & \text { Intern } \\ \text { H } & \text { Intern }\end{array}$

TABLE 2: Overview of working and internship place.

\begin{tabular}{l|c|c} 
& $N$ & $\%$ \\
\hline $\begin{array}{l}\text { Department in Internship } \\
\text { Human Resource }\end{array}$ & 6 & 26.09 \\
\hline $\begin{array}{l}\text { Marketing } \\
\text { Administration and General } \\
\text { Affair }\end{array}$ & 7 & 17.39 \\
\hline $\begin{array}{l}\text { Finance } \\
\text { Medical Record }\end{array}$ & 1 & 30.43 \\
\hline Research and Development & 1 & 4.35 \\
\hline Others & 2 & 8.35 \\
\hline Place of internship & & 8.70 \\
\hline Hospital & 19 & 82.61 \\
\hline Non-healthcare Institution & 4 & 17.39 \\
\hline
\end{tabular}

general affair, finance, medical record, research and development and other departments. Most of alumni and intern works on human resource department. Place of internship is divided by two places which are hospital and non-healthcare institutions.

Based on the result, interns mostly have good score for seven indicators and merely ability to use English that has a less score. The component that has the highest very good score is ability to use technology information device and teamwork which is 
TABLE 3: Overview of intern performance.

\begin{tabular}{|c|c|c|c|c|c|c|c|c|}
\hline \multirow{2}{*}{$\begin{array}{l}\text { Assessed } \\
\text { Expertise }\end{array}$} & \multicolumn{2}{|c|}{ Less } & \multicolumn{2}{|c|}{ Adequate } & \multicolumn{2}{|c|}{ Good } & \multicolumn{2}{|c|}{ Very Good } \\
\hline & $N$ & $\%$ & $N$ & $\%$ & $N$ & $\%$ & $N$ & $\%$ \\
\hline Integrity & 0 & 0.0 & 3 & 13.0 & 16 & 69.6 & 4 & 17.4 \\
\hline Professionalism & 0 & 0.0 & 3 & 13.0 & 18 & 78.3 & 2 & 8.7 \\
\hline Language & 1 & 4.3 & 7 & 30.4 & 14 & 60.9 & 1 & $4 \cdot 3$ \\
\hline Technology & 0 & 0.0 & 2 & 8.7 & 14 & 60.9 & 7 & 30.4 \\
\hline Communication & 0 & 0.0 & 4 & 17.4 & 13 & 56.5 & 6 & 26.1 \\
\hline Teamwork & 0 & 0.0 & 2 & 8.7 & 14 & 60.9 & 7 & 30.4 \\
\hline Self-development & 0 & 0.0 & 4 & 17.4 & 15 & 65.2 & 23 & 17.4 \\
\hline
\end{tabular}

$30.4 \%$. Meanwhile, ability to use English is the component that has the highest score as adequate rather than other components which is $30.4 \%$.

For integrity component, $69.6 \%$ intern and alumni have good score and $17.4 \%$ have very good score. In the professionalism component, 78.3\% alumni and intern have good score and merely $8.7 \%$ who have very good score. In ability to use English in working process, respondents deemed $4.3 \%$ of alumni have less ability and $30.4 \%$ have good score and only $4.3 \%$ have very good score.

TABLE 4: Performance problems based on the informants perce
\begin{tabular}{ll} 
Informant & Problem \\
C,D & $\begin{array}{l}\text { Lack of ability to operate Microsoft } \\
\text { Excel }\end{array}$ \\
\hline I, & $\begin{array}{l}\text { Lack of information regarding } \\
\text { intern's job detail or type during } \\
\text { internship program }\end{array}$ \\
G & $\begin{array}{l}\text { Lack of information given by } \\
\text { campus regarding job vacancy }\end{array}$ \\
D & $\begin{array}{l}\text { Lack of ability to do several job } \\
\text { affair }\end{array}$
\end{tabular}

Several problems have been expressed by informants during job performance assessment. Informants said there was a lack of information regarding job vacancy and intern job details that given by campus. Other problems are related to the skill of alumni and intern which are lack of ability to operate some computer program and some job affair. 
TABLE 5: Suggestion regarding job performance from informants.

\begin{tabular}{|c|c|}
\hline Informant & Problem \\
\hline A, B & $\begin{array}{l}\text { Increasing knowledge and expertise regarding INA } \\
\text { CBG's coding }\end{array}$ \\
\hline A & $\begin{array}{l}\text { Increasing skill regarding developing queuing online } \\
\text { application system }\end{array}$ \\
\hline$C, D$ & $\begin{array}{l}\text { Student should have getting module and certification } \\
\text { about using Microsoft Excel in Hospital }\end{array}$ \\
\hline $\mathrm{B}, \mathrm{H}, \mathrm{I}$ & University should open Diploma 4 degree \\
\hline B & $\begin{array}{l}\text { Knowledge regarding health sciences and medical } \\
\text { terminology must be increased }\end{array}$ \\
\hline$C, F$ & $\begin{array}{l}\text { Student should be taught about working under } \\
\text { pressure condition }\end{array}$ \\
\hline$A, E$ & Increasing expertise regarding using foreign language \\
\hline C & $\begin{array}{l}\text { Students should be taught about adaptation and } \\
\text { loyalty to the company }\end{array}$ \\
\hline C & Students should be taught about self-development \\
\hline \multirow[t]{3}{*}{ IJ } & $\begin{array}{l}\text { University should give detail and specific job to the } \\
\text { company before internship program }\end{array}$ \\
\hline & $\begin{array}{l}\text { Field supervisor need to give direction and lecture } \\
\text { before internship program had started }\end{array}$ \\
\hline & $\begin{array}{l}\text { University should organize ceremony before } \\
\text { internship had started }\end{array}$ \\
\hline \multirow[t]{3}{*}{ G } & $\begin{array}{l}\text { University should have agreement with hospital to } \\
\text { execute early recruitment before diploma has been } \\
\text { issued }\end{array}$ \\
\hline & University should accommodate alumni network \\
\hline & $\begin{array}{l}\text { University has website or social media for updating } \\
\text { information regarding job vacancy and development } \\
\text { of profession }\end{array}$ \\
\hline D & Increasing practice in educational process \\
\hline
\end{tabular}

Informants also gave several suggestions for increasing competencies of alumni and intern. Several suggestion regarding increasing of soft skill of alumni and students and other suggestions is about enhancing knowledge and skill regarding operating Microsoft excel, coding in INA CBG's application and knowledge about medical terminology. Soft skill such working in under pressure condition also should be taught by University so that student could be more prepared in working world. 
Indeed knowing foreign language is the most important thing in this global market era. With knowing foreign language, workers could give maximum service and could give a good image for the consumer [3].

\section{Conculsion}

Respondents assumed that alumni and intern from hospital administration program, vocational program, Universitas Indonesia have good skill in their job performance. Several problems have been expressed by informants such lack of ability for operating Microsoft excel and lack of ability to using foreign language. Some recommendations also have been conveyed by informants such adding certification in operating computer program and also adding soft skill in educational process. Researcher recommends that education curriculum and competencies of students have to be bridged by industrial need so that student could be more ready to enter working world.

\section{Acknowledgment}

The author would like to thank the Head of the Department of Vocational Program, Universitas Indonesia and also the Hospital Manager and other Managers at the Internship places who have given the permission to conduct the research.

\section{References}

[1] EFA Global Monitoring Report Team. "Education for all: the quality imperative." 2005.

[2] The Asean Secretariat Jakarta. "Asean State of Education Report 2013. ASEAN. February 2014.

[3] Setyanto, Aji. Pentingnya Penguasaan Bahasa dan Budaya Asing Sebagai Pendukung Utama Sektor Pariwisata. 